\title{
O ATREVIMENTO E O INSÓLITO EM A MAIOR FLOR DO MUNDO DE SARAMAGO
}

Eloísa Porto Corrêa

Resumo: Este trabalho abordará como o narrador saramaguiano enfoca o insólito e prega o atrevimento em A maior flor do mundo, procurando encorajar o leitor a ler, pesquisar, escrever, mas também a atrever-se e a reescrever do seu modo a(s) história(s) ou a História. No conto, como em muitas obras de Saramago, o insólito aparece como elemento desestabilizador, tirando personagens da mesmice ou da acomodação. É o que ocorre com os moradores do povoado do "herói menino", que saem do marasmo e quebram sua rotina ao se depararem com a obra extraordinária do infante: "a maior flor do mundo". A ousadiado menino é recompensada com a aclamação popular, e usada pelo narrador para incentivar o leitor a ousar também, a recriar, e a não se conformar com o senso comum ou com verdades prontas.

Palavras-chave: Saramago, Conto Infantil, Atrevimento, Insólito.

Abstract: This paper focuses on Saramago's narrator's approach to the unusual and his bold attitude in Amaiorflor do mundo. It also tackles on the way the reader is not only encouraged to read, research or write but also to dare rewrite History (or histories) individually. In this short-story, as in many other works by Saramago, the unusual appears as an unexpected and destabilizing element, shaking his characters' foundations and changing their view of the world,their own storyor History. This is what happens to the heroic boy's community, who lets go of their boring old lifestyle and breaks up with their routine when facing the infant's extraordinary work: "the largest flower in the world". In such text, the boy's boldness and audacity are rewarded with his popular acclaim and with the way he encourages the reader to recreate his/her own universe, never conforming with mediocrity or readymade truths.

Keywords: Saramago, children's short story, audacity, unusual. 
Segundo Maria Alzira Seixo, são recorrentes em Saramago certas temáticas, motivos e atitudes notados em vários romances do autor e no conto em análise neste trabalho, tais como:

no que diz respeito à temática: a relação identidade/alteridade; a articulação entre o homem e a terra; o projeto humano e a sua transposição, ou transcendência. (...) No que diz respeito à constelação de motivos preferenciais que preenchem essa temática: a água, [entre outras]. (...) Também nas atitudes dominantes: cepticismo radical no limite do desengano em fulgurações entretecido por um ilimitado entusiasmo na capacidade de construção humana, no projecto que é o sonho; mas também ainda na frase tensa que não se fecha completamente à irrupção lírica, na mordacidade que não exclui a ternura, na ironia que sempre traz a cumplicidade do afago. (SEIXO, 1987, p.15-16, grifos nossos)

Acrescentamos a esta constelação de motivos, o insólito, e à lista de atitudes, o atrevimento, que serão abordados nesse artigo, numa análise do conto $A$ maior flor do mundo, em confronto com outras obras de Saramago.

Passaremos agora, ao apontamento de algumas manifestações do insólito no conto. Em seguida, analisaremos o atrevimento nas atitudes do personagem principal e do 
narrador, que incentiva o leitor a ousar também. Durante a análise do conto, serão pontuados alguns exemplos de motivos, temáticas e atitudes, mencionados por Seixo no fragmento crítico acima.

O insólito, segundo García, Volobuef e Gama-Khalil, considerando estudos de Todorov, de Bessiere, de Sartre, de Freud, de Carpentier ou de Chiampi, entre outros:

abarca uma diversidade significativa de manifestaçõesestéticas em que o trabalho ficcional é sustentado pela emergência de situações que geralmente colocam o leitor em contato com o desconhecido, inexplicável.

Pode-se sugerir a manifestação do insólito ficcional sempre que elementos de qualquer das categorias da narrativa - tempo, espaço, personagem ou ação - provoquem, nos seres da ficção - narrador, narratário, personagem - e/ou nos seres da realidade - leitor real - um incômodo. Trata-sede uma impossibilidade de leitura passiva e pacífica, comportada e conformada, em que se tem amarca da negação presente em insólito, inaudito, incomum, inusual, inusitado, inesperado, insuficiente, incongruente, infame, incorrigível, ilógico, incrível, inverossímil, irreal, infinito, ou setem um transbordamento diante das expectativas, atingindose o extraordinário - para além daordinariedade - ou o sobrenatural 
- para alem da naturalidade - e, mesmo, a decepção ou a frustração. $O$ insólito ficcional condiciona um ato de leitura desconfortante, que independe dosvalores éticos ou estéticos do leitor real. (GARCÍA; VOLOBUEF; GAMA-KHALIL, 2011, grifos nossos)

Nas obras de Saramago, há várias manifestações do insólito que, muitas vezes, desestabilizam as vidas dos personagens e geram peregrinações, demandas por crescimento individual ou a união em comunidades. É o que ocorre em $\mathrm{O}$ Homem Duplicado, quando Tertuliano, ao se deparar com um insólito duplo seu, idêntico fisicamente, entra em crise em demanda por sua identidade perdida, fortalecendo-se e crescendo na narrativa. É o que ocorre também em A Jangada de Pedra, em que os personagens principais, após vários acontecimentos insólitos e a insólita fratura da Península, buscam seu lugar no mundo, apoiando-se e ajudando-se mutuamente, numa convivência comunitária que os fortalece. E é o que ocorre também em Ensaio sobre a Cegueira, uma vez que os cegos lutam por uma nova organização social, após a insólita cegueira branca que Ihes acomete e invalida a antiga ordem social; levando a mulher do médico a liderar uma pequena comunidade, que fortifica os seus integrantes na luta pela sobrevivência e pela readaptação. 
Em A maior flor do mundo, um evento insólito se apresenta já no título, como em $O$ Homem Duplicado. Mas, no conto infantil de Saramago, não será o evento insólito o motivador da peregrinação do personagem principal, e, sim, uma inquietação natural da criança, em busca de aventuras e conhecimento, que se soma à busca afetuosa de auxiliar o próximo, no caso, um outro ser vivo, uma "flor murcha". Insólita, no conto infantil, será, não apenas a peregrinação empreendida pelo "herói menino" para salvar essa "flor murcha", como também o resultado conseguido por ele, o crescimento exacerbado, extraordinário da flor salva.

Desce o menino a montanha, Atravessa o mundo todo, Chega ao grande rio Nilo, No côncavo das mãos recolhe Quanto de água lá cabia, Volta o mundo a atravessar, Pela vertente se arrasta, Três gotas que lá chegaram, Bebeu-as a flor sedenta.

Vinte vezes cá e lá, Cem mil viagens à Lua, O sangue nos pés descalços, Mas a flor aprumada Já dava cheiro no ar, E como se fosse um carvalho Deitava sombra no chão. (SARAMAGO, 2001)

O que o menino faz com a flor também não é insólito nem extraordinário, ele a rega. É insólito e extraordinário 
o que torna essa matéria depois do tratamento do "herói menino", menino comum até sua ousadia de atravessar o desconhecido, desafiar o novo para, num gesto afetuoso e corajoso, salvar uma flor.

A primeira situação-problema enfrentada pelo menino herói é a rotina, que ele decide quebrar, "Vou ou não vou? E foi", buscando "aventuras fora da sossegada terra onde vivem os pais", (SARAMAGO, 2011). Logo depois, encontra uma nova situação-problema: salvar uma flor murcha, que o lançará em nova e mais intensa aventura. Esses problemas, na verdade, são problemas e soluções, pois servem de pretexto para que ele quebre a rotina e viva as novas experiências que deseja. Cada novo obstáculo é, pois, solução para a falta de aventuras e novas experiências, a saída para o problema da rotina.

O narrador constrói os elementos da narrativa marcados pelo insólito: tempo e espaço incongruentes, certos personagens incomuns (menino atrevido e flor maior) e suas ações extraordinárias, para que provoquem um incômodo nos seres acomodados da ficção e no leitor. Através desses elementos, o narrador não apenas renega certas atitudes humanas nada construtivas e a negligência diante da natureza e do próximo, mas também sugere possibilidades de ação mais éticas, ainda que incomuns. 
O tempo se dilata para que grandes distâncias sejam rapidamente vencidas pelo menino. As fronteiras entre os países não são aproximadas, ao contrário, as hipérboles agigantam os percursos: "Desce o menino a montanha, / Atravessa o mundo todo, / Chega ao grande rio Nilo, (...) / Volta o mundo a atravessar, (...) / Vinte vezes cá e lá, / Cem mil viagens à Lua" (SARAMAGO, 2011).

Mas o tempo parece um aliado do herói, possibilitando ao menino se deslocar velozmente pelo globo terrestre e até pelo universo, desenvolvendo um número enorme de atividades num insignificante espaço de tempo.

A imaginação e a fantasia da infância parecem favorecer esse alargamento do tempo e a competência do herói para cumprir tarefas incríveis, superar distâncias e obstáculos incontáveis.

Uma situação estranha, aliás, abre o conto: o narrador de uma história infantil que afirma não saber escrever para crianças e mesmo assim vai escrevendo um conto para estas lerem:

As histórias para crianças devem ser escritas com palavras muito simples, porque as crianças sendo pequenas, sabem poucas palavras e não gostam de usá-las complicadas. Quem me dera saber escrever essas histórias, mas 
nunca fui capaz de aprender, e tenho pena. Além de ser preciso saber escolher as palavras, faz falta um certo jeito de contar, uma maneira muito certa e muito explicada, uma paciência muito grande e a mim falta-me pelo menos a paciência, do que peço desculpa.

Se eu tivesse aquelas qualidades todas poderia contar, com pormenores, uma linda história que um dia inventei, mas que, assim como a vão ler, é apenas o resumo de uma história, que em duas palavras se diz... (SARAMAGO, 2001.)

Há uma preocupação metatextual por parte do narrador, compartilhada com o leitor, que é convidado para uma reflexão sobre o fazer literário, sobre o projeto estético da obra. Para além disso, como é costume na obra de Saramago, o conto também apresentará uma perspectiva pedagógica, que será analisada mais adiante.

O narrador, que assume a função de escritor e leitor de contos infantis, apresenta uma primeira concepção sobre como deve ser um conto infantil: a do senso comum. Elenca elementos que não podem faltar a uma obra escrita para crianças, mas ironicamente se diz incapaz de escrever com esses elementos, seguindo a receita do senso comum.

O narrador-escritor saramaguiano se expõe ao leitor, expõe suas fragilidades, seus receios, eliminando a distância 
entre o autor e o leitor, entre o escrever e o ler. Além disso, ao apresentar-se como incapaz de produzir o texto, parece querer encorajar melhor o leitor a escrever ou a ensaiar a escrita, em busca de formar escritores críticos para o público mirim ou no público mirim. Se o narrador não sabia e escreveu, a criança também conseguirá: "Quem sabe se um dia virei a ler outra vez esta história, escrita por ti que me lês, mas muito mais bonita?..." (SARAMAGO, 2001).

Enquanto escreve a história que afirma não ter tido competência para escrever, eleparece realçar a necessidade de palavras descomplicadas nas histórias infantis, não apenas usa palavras complicadas, como encoraja os leitores a pesquisarem. Mostra, com isso, a importância de se incentivar a pesquisa entre as crianças e a ampliação vocabular e, sobretudo, mostra que as crianças têm, evidentemente, capacidade para isso:

$\mathrm{Na}$ história que eu quis escrever, mas não escrevi, havia uma aldeia. (Agora vão começar a aparecer algumas palavras difíceis, mas, quem não souber, deve ir ver no dicionário ou perguntar ao professor) (SARAMAGO, 2001).

A valorização do livro, do saber acumuladoe do professor são patentesno início da obra. Mas, ao final do livro, abre-se um espaço maior para a criança como agente no processo 
educativo e social. Abre-se, entre esses importantes elementos da cultura, um lugar de destaque para os saberes da criança, suas potencialidades, experiências e a inovação, as descobertas que sempre podem fazer. Isso porque é o menino quem ousa, quem se atreve a fazer diferente de todos os outros, aquele que inova:

Quando depois passava pelas ruas, as pessoas diziam que ele saíra da aldeia para ir fazer uma coisa que era muito maior do que o seu tamanho e do que todos os tamanhos (SARAMAGO, 2001).

E são as crianças, leitores do livro infantil, que escreverão as novas histórias, não no futuro, mas agora.

Duma maneira corrosiva, o narrador apresenta a concepção tradicionalista sobre histórias infantis, mas a desconstrói ao longo do seu conto, já que afirma que as palavras deveriam ser simples, porém escreve usando "palavras difíceis". E, por fim, desqualifica ou relativiza os saberes dos adultos, afirmando que eles não sabem o que ensinam e poderiam/ deveriam aprender com os contos das crianças: "E se as histórias para crianças passassem a ser de leitura obrigatória para os adultos? Seriam eles capazes de aprender realmente o que há tanto tempo têm andado a ensinar?" (SARAMAGO, 2001).

A paciência que o narrador afirma, de início, ser necessária para a confecção dessa literatura fácil para as crianças é 
também desconstruída, uma vez que o narrador se diz sem paciência e sem habilidade, mas, mesmo assim, a obra é produzida, e é compreendida e debatida por crianças de diferentes idades. Isso prova que, segundo sua experiência, cada criança é capaz de problematizar obras diferentes, que não precisam ser simplistas ou facilitadas como pediria o senso comum ou tantas pedagogias que ensinam como ensinar às crianças, que palavras usar com elas.

O encorajamento do leitor se dá o tempo inteiro na obra, condizente com uma certa finalidade pedagógica que sempre notamos nas obras do marxista Saramago, com sua raiz neorrealista: "Não se temam, porém, aqueles que fora das cidades não concebem histórias nem sequer infantis" (SARAMAGO, 2001). Entretanto, não se trata de uma finalidade pedagógica opressora ou tradicionalista, mas aberta, dialógica. A obra se quer abrir para todos os públicos infantis: os da cidade, do campo; os mais letrados e os menos letrados também. O narrador encoraja o leitor não apenas a conhecer essa história, mas também a reescrevê-la: “Quem sabe se um dia virei a ler outra vez esta história, escrita por ti que me lês, mas muito mais bonita?...." (SARAMAGO, 2001).

Além dessa "relação de alteridade/identidade" construtiva e da "articulação entre homem e terra" na relação entre 
o menino e a flor, notamos, no conto, uma tentativa de resgate da harmonia entre o homem, o ambiente e seus pares. Isso não significa, no entanto, condenar a civilização ou aconstrução humana, já que é para lá que o menino volta depois de cuidar da flor. Trata-se de uma busca de harmonia ou equilíbrio entre os elementos culturais e os naturais, a possibilidade de uma ação menos nociva do homem sobre a natureza e seus semelhantes, também notada em obras como Levando do Chão.

No conto, como em outras obras de Saramago, há duplos ou elementos que se espelham, como ocorre com a flor e o menino, já que ele cuida dela primeiro e, depois, ela cuida dele. Outrocaso de duplicação na narrativa é a do menino -duplo do agricultor e também do escritor -, que rega a flor e ela cresce e se desenvolve mais do que o esperado, assim como o escritor pode escrever e cultivar a sua obra (infantil ou não), e ela se desenvolverá mais do que o esperado. Nesse caso, o leitor torna-se duplo do escritor, uma vez que é convidado a reescrever a história ou, por extensão, as histórias e a História, que o narrador espera ler "escrita por ti que me lês, mas muito mais bonita" (SARAMAGO, 2011). Outro caso de duplo é o do menino e o pintassilgo. Nesse caso, como o duplo da flor, reforça-se a articulação entre o 
homem e a natureza. Assim como a ave precisa de liberdade e de natureza, o menino também precisa de liberdade e religação com a naturezapara se desenvolver bem e feliz.

Logo na primeira página, sai o menino pelosfundos do quintal, e, de árvore em árvore, como um pintassilgo, desce ao rio e depois por ele abaixo, naquela vagarosa brincadeira que o tempo alto, largo e profundo da infância a todos nós permitiu...(SARAMAGO, 2001)

Ultrapassar limites, se aventurar, explorar e experimentar muito aparece como algo necessário para o desenvolvimento do "herói menino" da narrativa:

Em certa altura, chegou ao limitedas terras até onde se aventurara sozinho. Dali para diante começava o planeta Marte, efeito literário de que ele não tem responsabilidade, mas com que a liberdade do autor acha poder hoje aconchegar a frase. Dali para diante, para o nosso menino, será só uma pergunta sem literatura: "Vou ou não vou?» $E$ foi. (SARAMAGO, 2001)

A liberdade do menino, aprendiz de escritor, como de agricultor, cultivador de flores (podem ser também livros), faz par com a liberdade ou a licença literária do escritor ao criar, ousar com palavras. Recriar o seu mundo com gestos é o atrevimento do menino herói. Recriar o mundo com palavras é o atrevimento do narrador-escritor. 
Atrevimento, segundo o Aurélio, é a "ação de atrever-se, ousadia, coragem, arrojo, petulância, audácia, insolência". E atrever-se significa "atribuir-se a capacidade de fazer algo, ter a ousadia ou a coragem necessária para fazer ou tentar alguma coisa." (AURÉLIO, 1999, p.228). E o menino atrevese, primeiramente, a sair do caminho rotineiro e, depois, diante da carência da flor, atribui-se a capacidade de salvála. Tem a ousadia e a coragem necessárias para fazer ou tentar alguma coisa e não apenas salvá-la, como a torna surpreendentemente grande.

A recompensa pelo trabalho extraordinário e despretensioso dele, uma peregrinação insólita para salvar uma flor murcha, é bem maior do que poderia esperar: não apenas a devolução da saúde e da dignidade à flor, mas o seu engrandecimento e, com ele, o engrandecimento do próprio personagem, aclamado pelo seu povo. Essa relação de alteridade afetuosa e construtiva, observada no relacionamento que o "herói menino" estabelece com a flor, leva-o a amparar no primeiro momento e, depois, ser por ela amparado: "O menino adormeceu debaixo da flor. (...) Sobre ele, resguardando-o do fresco da tarde, estava uma grande pétala perfumada, com todas as cores do arco-íris" (SARAMAGO, 2011). Com isso, os dois crescem na obra: a flor se engrandece, o menino é aclamado pelo povo e ambos 
ganham destaque. Estamos diante da relação identidadealteridade de que fala Seixo, já que o menino se afirma, consolida sua identidade, aprende e cresce na relação com o outro, nesse momento, a flor e, em outros, com a família ou a sua comunidade.

No olhar que o narrador lança para esse construtivo projeto do personagem e para o seu produto final: "a maior flor do mundo", notamos também o "ilimitado entusiasmo na capacidade de construção humana", a partir do "projeto que é o sonho" (SEIXO, 1987, p.18). "Esse projeto é o sonho" de trazer dignidade ao outro, que leva o menino a ajudar uma flor no conto infantil; e levou "a mulher do médico" a ajudar um grupo de cegos, em Ensaio sobre a Cegueira; e levou um solitário e entediado escriturário, responsável pelos processos de todos os vivos e mortos de sua localidade, a embaralhar os arquivos dos vivos e dos mortos, "antes autoritariamente dispostos em espaços excludentes", em Todos os Nomes.

Essa busca bem sucedida de dignidade para o outro acaba por trazer dignidade e reconhecimento para o menino, além de tirar do marasmo a aldeia. Todos os personagens ganham quando cuidam uns dos outros na obra de Saramago. $\mathrm{O}$ individualismo leva à solidão, ao isolamento ou 
à abulia do Tertuliano do início de $O$ homem duplicado ou à autodestruição do Antônio Claro, ou a uma sobrevivência indigna para muitos cegos em Ensaio sobre a Cegueira.

Na reação do povoado ao tomar conhecimento da "maior flor do mundo" e da contribuição do menino para esse acontecimento, também percebemos, mais uma vez, esse "entusiasmo na capacidade de construção humana" (SEIXO, 1987, p.18), de que nos fala Seixo: "Quando depois passava pelas ruas, as pessoas diziam que ele saíra da aldeia para ir fazer uma coisa que era muito maior do que o seu tamanho e do que todos os tamanhos" (SARAMAGO, 2001). Essa insólita criação do menino desestabiliza a mesmice da vida dos moradores da aldeia, tirando-os do marasmo.

Fugir do rotineiro, do costumeiro é um traço que liga o narrador e o herói menino, que se vai para longe do rio, pelo caminho novo, desconhecido e misterioso, como faz o narrador escrevendo de uma maneira diferente da receitado senso comum.

O rio fazia um desvio grande, afastava-se,e de rio ele estava já um pouco farto, tanto queo via desde que nascera. Resolveu cortar a direito pelos campos, entre extensos olivais, ladeando misteriosas sebes cobertas de campainhas brancas, e outras vezes metendo por bosques de altos freixos onde havia clareiras macias 
sem rasto de gente ou bicho, e ao redor um silêncio que zumbia, e também um calor vegetal, um cheiro de caule sangrado de fresco como uma veiabranca e verde. (SARAMAGO, 2001, grifo nosso)

A fuga do rotineiro fica marcada até na construção dos insólitos cenários e ambientes misteriosos, através de sinestesias que interpenetram imagens, luminosidades, sons, cheiros e sensações táteis, no trajeto do menino pela novidade: "clareiras macias sem rasto de gente ou bicho", "um silêncio que zumbia", "um calor vegetal, um cheiro de caule sangrado de fresco como uma veia branca e verde" (SARAMAGO, 2011). A sinestesia parece reiterar a noção de união ou unidade, de harmonia e de integração entre todos os elementos que compõem a natureza, à qual o menino também parece bem integrado, já que em nenhum momento é agredido ou agride o ambiente natural em que transita. Narrador e protagonista reparam a natureza, sentem-na, admiram-na, analisam-na com atenção, respeitam-na, preservam-na, relacionam-se construtivamente com ela. $\mathrm{O}$ menino se integra à natureza e o narrador reivindica uma maior integração do homem com ela.

Foi um desvio do hábito, uma decisão ousada do menino, cansado da rotina ("de rio estava farto"), um atrevimento (“Dali para diante começava o planeta Marte"; "Vou ou não 
vou? E foi."), que levou o menino à flor e outros depois que o levaram a ajudá-la. Mas, a quebra da rotina, o desvio de curso do menino aparece como algo natural, que ocorre na natureza, já que também "o rio fazia um desvio grande, afastava-se" (SARAMAGO, 2011). Manter-se no marasmo sempre ou por muito tempo é que não parece tão natural na narrativa. Estamos mais uma vez diante de um processo de duplicação no conto, agora entre o desvio de curso do rio e o do menino, naturalmente aventureiro e curioso.

Não é o narrador do conto o único na obra de Saramago que defende o atrevimento e a quebra da rotina ou do marasmo. Foi um atrevimento apoiado pelo narrador que levou Espada a desafiar o latifundiário, em Levantado do Chão; e que levou a tríade Blimunda, Bartolomeu e Baltasar a planejar e construir a passarola em Memorial do Convento; e foi um atrevimento do antes abúlico Tertuliano que o levou a desafiar seu duplo em $O$ homem duplicado. A obra de Saramago provoca o homem sempre a atrever-se e a mudar de curso, como o rio e o menino fazem no conto. Os narradores de Saramago incentivam a não se conformar com rotinas, a não se acomodar acostumes, seja a do povo da "sossegada terra onde vivem os pais" (SARAMAGO, 2011) do menino; ou a de dominações, tiranias e explorações, 
em Levantado do Chão e Memorial do Convento; ou a de abulias, em $O$ homem duplicado.

Outra rotina quebrada no conto é a de negligência com a natureza, que circunda a flor, mal cuidada. O "herói menino" cuidadoso, construtivo, irá cultivar e não devastar, explorar ou se conformar com o estado de abandono da flor, da natureza. E essa é uma das lições que os adultos têm ensinado, mas ainda precisam aprender com as histórias de crianças, como afirma o narrador ao fim do conto.

No conto, além da terra e da flor, junta-se "à constelação de motivos preferenciais que preenchem essa temática" da busca de "articulação entre o homem e a terra" (SEIXO, 1987, p.15-16), de que nos fala a autora: "a água", elemento vivificador, metáfora de vida e purificação. A água é, a custo, alcançada pelo menino no conto, e é decisiva para a salvação da flor e para a harmonia entre o homem e o ambiente. A água chega à flor por intermédio do menino, que enfrenta obstáculos e provações heroicamente, de acordo com o narrador, vencendo distâncias, superando obstáculos, como se viu.

No local mais difícil de acessar, estará o semelhante do menino, outro ser vivo carecendo de cuidado, que virará personagem, a flor murcha precisando de cultivo. 
Ó que feliz ia o menino! Andou, andou, foram rareando as árvores, e agora haviauma charneca rasa, de mato ralo e seco, e no meio dela uma inóspita colina redonda como uma tigela voltada.

Deu-se o menino ao trabalho de subir a encosta, e quando chegou lá acima, que viu ele? Nem a sorte nem a morte, nem as tábuas do destino... Era só uma flor. Mas tão caída, tão murcha, que o menino se achegou, de cansado. E como este menino era especial de história, achou que tinha de salvar a flor. Mas que é da água? Ali, no alto, nem pinga. Cá por baixo, só no rio, e esse que longe estava!... Não importa. (SARAMAGO, 2001)

Os personagens dessa literatura não parecem extraordináriosou fora do comum ao início da narrativa: "Era só uma flor", "tão caída, tão murcha"; "sai o menino pelos fundos do quintal, (...) naquela vagarosa brincadeira que o tempo alto, largo e profundo da infância a todos nós permitiu" (SARAMAGO, 2001). Mas são retirados de suas vidas comuns, cotidianas e crescem, ganham representatividade na obra. Só após a intervenção do "herói menino", a flor comum e sem importância ganha vulto e força, elevação. O mesmo ocorre com o menino comum, que se torna herói por seus gestos para com a flor. Como em toda a obra de Saramago, são "levantados do chão" seres esquecidos e negligenciados, são tirados do 
anonimato "formigas" que constroem conventos e meninos que cuidam da natureza.

No conto infantil também, como em toda a obra para adultos, o autor prega a reescrita da História, a construção de novas versões com pontos de vista de personagens comuns, esquecidos ou silenciados na Historiografia oficial. A História passa a ser considerada uma das histórias e não mais o discurso de uma verdade inquestionável, que reproduz o discurso de um dominador ou um discurso dominador.

Nessa concepção, como diria Cerdeira, orientada por Georges Duby, “História é acima de tudo uma arte, uma arte essencialmente literária" (SILVA, 2000, p.284). A literatura cumpre, desse modo, um papel importante na construção de versões para os acontecimentos, uma vez que a própria História é reconhecida como uma versão criada entre as versões possíveis para um fato. A literatura pode dar voz a grupos silenciados na versão da Historiografia oficial. Além disso, escrever literatura pode se apresentar como possibilidade de projetar transformação histórica e social ou como diria o narrador de Manual de Pintura e Caligrafia:

Escrever não é outra tentativa de destruição, mas antes a tentativa de reconstruir tudo pelo lado de dentro, 
medindo e pesando todas as engrenagens, as rodas dentadas, aferindo os eixos milimetricamente, examinando o oscilar silencioso das molas e a vibração rítmica das moléculas no interior dos aços. (SARAMAGO, 1976)

É o gesto de levantar o outro, de retirá-lo do estado de indignidade e de dormência, construindo uma nova versão da História ou das histórias, que eleva também o escritor e o menino herói. Um porque reescreve a História com palavras e o outro porque a reescreve com atos e gestos. Não se eleva o escritor ou o herói da obra por salvar ou louvar uma figura ilustre ou um membro da elite, mas por valorizar o humilde, elevar o cotidiano, revitalizar o negligenciado ou o excluído. Isso é o que traz projeção ao menino e ao narrador-escritor do conto.

Esse trabalho do personagem (como o do escritor) é demorado, árduo e requer perseverança, dedicação, cuidado, amor ao próximo e comprometimento, mas recompensa o narrador-escritor, herói-menino, como a flor recompensou o menino, protegendo-o, proporcionando involuntariamente a ele o reconhecimento público, a admiração dos outros homens pelo seu trabalho e esforço: "Este menino foi levado para casa, rodeado de todo o respeito, como obra de milagre."; “Quando depois passava pelas ruas, as pessoas 
diziam que ele saíra da aldeia para ir fazer uma coisa que era muito maior do que o seu tamanho e do que todos os tamanhos" (SARAMAGO, 2001). O reconhecimento vem para esse menino ousado, que resgata a dignidade de uma flor murcha. Desse modo, o narrador-escritor pode usar sua obra para resgatar a dignidade de tantos personagens mesquinhos, maltratados por diferentes adversidades, como os membros da família Mau Tempo (SARAMAGO, 1980), como Tertuliano (SARAMAGO, 2002) ou os operários de Memorial do Convento (SARAMAGO, 1982).

Juntamente com o tipo de literatura que defende o autor, claramente filiada a uma raiz neorrealista e marxista, revelando também um existencialismo peculiar à sua segunda fase romanesca, o narrador não tenta disfarçar o caráter pedagógico de sua obra, assume que busca ensinar:

Quando depois passava pelas ruas, as pessoas diziam que ele saíra da aldeia para ir fazer uma coisa que era muito maior do que o seu tamanho e do que todos os tamanhos. E essa é a moral da história. (SARAMAGO, 2001).

Mas assume-se como um narrador-escritor-mestre, que ensina não a copiar ou imitar, ensina a reescrever, a transformar (o entorno e a si próprio), a ousar sem subjugar o outro ou oprimir. Ensina a reescrever a narrativa 
tradicional, a pedagogia, a História, a narrativa do mestre, condenando qualquer discurso opressor ou encerrado em si mesmo. Ensina que o diálogo intertextual e a reescrita devem ser perenes.

Mesmo depois de incentivar o leitor a se instruir, a pesquisar e a procurar "professores", valorizando o conhecimento acumulado e o letramento, a leitura; ao fim da narrativa, o narrador faz questão de criticar aqueles que julgam que o saber ou as experiências da criança não estão à altura das do adulto ou do conhecimento acumulado pela civilização. Da mesma forma, em outras obras de Saramago, os narradores afirmam o valor de outros grupos menosprezados, que costumam ter seus saberes e experiências diminuídos pelos grupos dominadores, como os humildes trabalhadores de Levantado do Chão ou os operários de Memorial do Convento eram diminuídos pelas elites: latifundiários, clérigos ou nobres.

Mas, por mais que deseje continuar a aventura literárioexistencial, o escritor, como também o agricultor mirim do conto, retorna sempre para a sua terra natal. Isso faz a fim de usar suas reflexões para enriquecer sua vida, aprender com o que produziu e aplicar esses conhecimentos, ou usar sua escrita-experiência para o próprio crescimento e para o crescimento do outro. O narrador não esquece ou ignora 
seus pares, suas origens, mas sempre volta para de algum modo ajudá-los, usando sua escrita para ensinar uma lição de amor à natureza e ao próximo. Estamos diante do "afago" e da "ternura", de que nos fala Seixo, que contrastam (mas convivem) com a "ironia" e a "mordacidade" no texto saramaguiano, como vimos ao longo desse artigo.

A aventura, a escrita, o conhecimento são uma experiência dolorosa para o próprio e para os seus entes queridos, pois exige dedicação e afastamento do seio familiar: "Correram tudo, já em lágrimas tantas, e era quase sol-pôr quando levantaram os olhos e viram ao longe uma flor enorme que ninguém se lembrava que estivesse ali."; "Passaram as horas, e os pais, como é costume nestes casos, começaram a afligirse muito. Saiu toda a família e mais vizinhos à busca do menino perdido. E não o acharam." (SARAMAGO, 2001). Mas, apesar de dolorosa, mostra-se compensadora aos personagens.

A aparente modéstia do narrador, na verdade, quer ressaltar tambémo amor e o comprometimento que o escritor precisa ter com sua matéria literária, sua obra e seu labor: "Que me seja desculpada a vaidade se eu até cheguei a pensar que a minha história seria a mais linda de todas as que se escreveram desde o tempo dos contos de fadas e princesas encantadas... Há quanto tempo isso vai!" (SARAMAGO, 2001). Por outro lado, o conto também ironiza 
o estatuto das histórias tradicionais, afastadas do cotidiano das crianças e dos problemas sociais, como se estas não pudessem entender tais problemas ou não devessem entrar em contato com eles. Ao contrário disso, o narrador de Saramago convida a criança arefletir, criticar, reescrever e mudar essa tradição, a acabar com o estatuto de verdade imutável de qualquer história, e busca uma ampliação das temáticas abordadas em contos infantis.

Portanto, "a linda história que um dia inventou [o narrador], mas que, assim como a vão ler, é apenaso resumo de uma história, que em duas palavras se diz..." (SARAMAGO, 2001) é a história do próprio "escritor", no sentido lato, aquele que, engrandecendo o outro em sua obra ou o outro e sua obra, acaba engrandecido e recompensado. Esse é um "novo atrevimento", a ousadia que transforma o futuro em glória, como pregou já, antes, Camões no seu épico. Assim como "o novo atrevimento", de que trata a epopeia camoniana, é tornado "metáfora do próprio poemae dos processos de sua composição" (MACEDO, 2007, p.270); da mesma forma, "o novo atrevimento" de Saramago é também sua obra, que conclama o leitor a se atrever e se tornar escritor de novas histórias ou da História com gestos ou palavras.

O menino torna-se uma alegoria do escritor e sua aventura, a aventura da própria escrita. Nessa aventura, identificam- 
se narrador, autor e até leitor, convidado a se tornar autor. Estamos mais uma vez diante do "ilimitado entusiasmo na capacidade de construção humana, no projeto que é o sonho" (SEIXO, 1987, p.15-16), de que o livro se torne um convite ao atrevimento, à ousadia, que duplicará a postura do menino, a do narrador, a do escritor, a de Saramago ou a dequem mais aprender com eles.

Na obra do autor, a experiência é valorizada, seja ela individual ou comunitária, sobretudo quando é usada de maneira construtiva, como a do grupo de cegos liderado pela mulher do médico, oposto àquele grupo de cegos exploradores, que destrói até se autodestruir. Mas, o vigor e a disposição para ousar, a inquietação e o atrevimento, comuns nos jovens, são indispensáveis para qualquer mudança necessária nas sociedades da ficção saramaguiana. As novas gerações em Levantado do Chão que foram garantindo as transformações necessárias para a emancipação do grupo de trabalhadores rurais oprimidos e explorados. No conto, é a ousadia e destemor, comuns na juventude, que levam o herói menino ao sucesso de sua empreitada.

Por isso, Saramago convoca o leitor do seu conto infantil a atrever-se, a complementar o seu "novo atrevimento", 
a sonhar e a construir, ou melhor, criar uma nova história, a partir desse seu "resumo de uma história, que em duas palavras se diz..." (SARAMAGO, 2001). O narrador valoriza aquele que lê, eleva-o e, mais, contesta o estatuto de verdade atribuído aos saberes dos adultos, enaltecendo os saberes dos infantes, por fim. Praticamente convoca os adultos a não apenas trocarem saberes com as crianças, mas a aprender com elas, que reescreverão tudo que receberem dos adultos, começando pelo conto A maior flor do mundo.

Da mesma forma que Saramago sempre reescreveu a História em sua literatura, também convida o leitor do seu conto a reescrever as histórias que ouve e nunca se conformar a elas, mas criticá-las, dialogar com elas inquietamente e inquietantemente, sem nunca pretender uma verdade inquestionável, como Saramago e Camões.

Torna-se a literatura um ato de amor. A escrita ou o processo da escrita torna-se um processo de elevação do pequeno, do negligenciado. E o resultado é a elevação dos dois: quem escreve e quem é (re)escrito. Ou melhor, dos três: quem escreve, quem é (re)escrito e quem lê e pode passar a (re)escrever sua vida e a de quem está em volta.

Assim, o narrador usa o insólito para ambientar o conto, provocar personagense leitores e expandir tempo, espaço e 
ações, valorizando gestos e atitudes do herói menino ousado. E o narrador focaliza o atrevimento desse herói menino para incentivar leitores e outros personagens a atreverem-se também, a não se conformarem, buscando agir e reescrever espaços, personagens e tempos, sociedades e histórias.

\section{REFERÊNCIAS:}

Camões, Luís Vaz de (1975). Os Lusíadas. Porto: Porto.

Cerdeira da Silva, Teresa Cristina (1984). José Saramago: entre a história e a ficção: uma saga de portugueses. Lisboa: Publicações D. Quixote. . (2000). O Avesso do Bordado: ensaios de literatura. Lisboa: Caminho.

Coelho, Nelly Novaes (1993). Literatura Infantil: teoria, análise, didática. São Paulo: Ática.

Ferreira, Aurélio Buarque de Holanda (1999). Novo Aurélio Século XXI: o dicionário da Língua Portuguesa. (3a ed.). Rio de Janeiro: Nova Fronteira. García, Flávio; Volobuef, Karin \& Gama-Khalil, Marisa (2011) Vertentes do insólito ficcional. ABRALIC.

Hall, Stuart (2003). A identidade cultural na pós-modernidade (7a ed.). (Tomaz Tadeu da Silva \& Guacira Lopes Louro, Trad.).Rio de Janeiro: DP\&A. Hutcheon, Linda (1991). Poética do pós-modernismo: história, teoria, ficção. (Ricardo Cruz, Trad.). Rio de Janeiro: Imago.

Lourenço, Eduardo(1978). O Labirinto da Saudade, Psicanálise Mítica do Destino Português (5a ed.). Lisboa: Publicações Dom Quixote.

Macedo, Helder. Camões e a Viagem Iniciática. (1980). Lisboa: Moraes Editores.

. (2007). Trinta Leituras. Lisboa: Editorial Presença.

Nascentes, Antenor de Veras (1952). Dicionário Etimológico da Língua Portuguesa. Tomo II - nomes próprios. Rio de Janeiro: Editora Francisco Alves. 
Proença Filho, Domício (1999). A linguagem literária(7a ed.). São Paulo: Ática.

Reis, Carlos (1998). Diálogos com José Saramago (p.103). Lisboa: Editorial Caminho.

Saraiva, Antônio José. Lopes, Oscar (1989). História da Literatura Portuguesa (15a ed.). Porto: Porto.

Saramago, José (2001). A Maior Flor do Mundo. [Ilustração: João Caetano]. Lisboa: Editorial Caminho.

.(2002). O homem duplicado. São Paulo: Companhia das Letras.

.(1982). O Ano da Morte de Ricardo Reis. Lisboa: Caminho.

. (1985). Ensaio sobre a Cegueira. Lisboa: Caminho.

. (1991). O Evangelho segundo Jesus Cristo. Lisboa: Caminho.

. (1989). História do Cerco de Lisboa. Lisboa: Caminho.

.(1983). In nomine Dei. Lisboa: Caminho.

- (1985). A Jangada de Pedra. Lisboa: Caminho.

. (1980). Levantado do Chão. Lisboa: Caminho.

. (1976). Manual de Pintura e Caligrafia. Lisboa: Moraes Editores.

- (1982). Memorial do Convento. Lisboa: Caminho.

. (1997). Todos os Nomes. Lisboa: Caminho.

Seixo, Maria Alzira (1987). O essencial sobre José Saramago. Porto: HCM. . (1986). A palavra do romance: ensaios de genealogia e análise.

Lisboa: Livros Horizonte.

Eloísa Porto Corrêa é pós-doutoranda da UERJ, Universidade do Estado do Rio de Janeiro, instituição onde se graduou em Letras e onde atuou como Professora Substituta entre 2003 e 2009. Concluiu o Doutorado em Letras Vernáculas (Literatura Portuguesa) em 2008, na UFRJ, Universidade Federal do Rio de Janeiro, onde cursou também o Mestrado na mesma área, entre 2003 e 2005, com bolsa da FAPERJ NOTA 10. Possui Especialização em Educação Artística pelo CEN/ CECAP e em Ensino de Língua Portuguesa e Literatura pela Fundação 
CECIERJ/CEDERJ, onde atualmente trabalha como tutora presencial. Atua também como Professora de Português, Literatura e Produção Textual da Prefeitura Municipal de Niterói e do Governo do Estado do Rio de Janeiro, e como Professora Adjunta I-Coordenadora do Curso de Letras na USS, Universidade Severino Sombra, onde leciona em Cursos de Graduação e Pós-Graduação e lidera dois grupos de pesquisa: 1-"Diálogos entre Literatura e Cultura nos Séculos XX e XXI", ativo desde 2008, com fomento da FUNADESP em 2011 e em 2012, e com orientação a bolsista PIBIC FUNADESP; 2-História de Vida de Professores de Ciências de Maricá, em 2013, com orientação a bolsista de PIBIC CNPq. Tem experiência nas áreas de Educação e Letras, com ênfase em Técnicas de Pesquisa, Língua e Literatura Portuguesa. 